ARCHIWUM FILOZOFII PRAWA

I FILOZOFII SPOŁECZNEJ

Karol Muszyński

University of Warsaw

\title{
Can Human Rights be More Than a Burden in the Post-crisis Recovery? A Review of Economic and Social Rights After the Financial Crisis, edited by Aoife Nolan, Cambridge University Press 2014
}

\section{Introduction - human rights and the global economic crisis}

When the seriousness of the economic crisis was revealed in US in 2007/8 and later in the Eurozone, the solutions thereto varied but one thing was certain - that a state of emergency was necessary. The state of emergency was to save the sacrosanct figure of the "economy", with GDP growth as an indicator of its health, through the remedies of austerity, financial consolidation, and deficit reduction. Supposedly, spending cuts had to be made in order to restore the principles of "sound finance". Human rights, especially economic and social ones (hereinafter: ESR), have been perceived as a surplus of the precrisis prosperity, often even somehow responsible for the financial imbalances and the crisis itself. The West was rich and it invented a framework justifying the expansion, or even "inflation", of rights that were to be provided by the state. Demanding population lured by opportunist politicians were expanding their claims to the extent not possible to be borne by the financial-institutional framework. That is why the statements that in order for the economy-restoring state of emergency to be successful certain rights must be reviewed and revoked dominate public discourse.

Much has been said on the impact the economic crisis has had on the condition of human rights, as well as on the relationship between human rights and economic globalization and problems of global governance. The book Economic and Social Rights After the Financial Crisis, edited by Aoife Nolan, however only partially falls into this mainstream. An interesting and dominating motive is not that human rights observance standards have deteriorated as a result of the crisis (which is a needed yet obvious remark), but rather that human rights should be used as a frame of reference when drafting solutions to overcoming the crisis. Most of the search for crisis solutions is concentrated around economic responses to the crisis, which are at the same time trying to understand its causes. The identified causes seem to show the way out towards "economic recovery". Was crisis caused by bad institutional frameworks that created unhealthy incentives for the financial sector, as institutional economists and Post-Keynesians say? So we should redesign the regulations and it will be gone. 
Were wages increasing more slowly than productivity, or - using other words to describe the same phenomenon - was the rising income inequality a contributing factor, as some other Post-Keynesians or Piketty ${ }^{1}$ claim? Then we should aim at a wage increase policy. Is crisis as such an inevitable part of the capitalist economy due to the business cycles? Start countercyclical measures. Did the excess of obscure regulations serving the interests of "crony" capitalists launch it, as Austrian theory says? Then overthrow those regulations.

Those perspectives have one thing in common. In systems theory language, they seem to hold constant the perspective of the domination of the economic system over the political one (speaking in political sociology terms - of "capitalism" over "democracy") that violates the functional differentiation of the society and, in my opinion, causes disturbances. The authors of the articles in the book stress that a shift in perspective is needed - one should focus on satisfying the economic and social rights (which will serve as a platform for a subsequent economic recovery) and not think on how to "simply" recover the economy which would supposedly start off an improvement of the condition of human rights (one could ironically call this a "trickle-down" solution).

The book therefore tries to critically approach the responses to the economic crisis that assume inevitability of the ESR "suspension" as a result of the crisis and suggest that human rights should be used as a principal basis for recovery, which simultaneously means that they should be instrumental in an analysis of the tools utilized to fight the crisis, most importantly public austerity measures.

I intend to make use of two primary frameworks to comment on the book - one of political sociology/political economy that I believe provides some comments and ideas challenging human rights' use in dealing with the crisis, and a systems theory approach to human rights that I perceive as potentially useful in providing a new perspective.

\section{Content of the book}

The book is divided into three parts. The first part concerns the international perspective of ESR protection - it intends to show the magnitude of damage caused to ESR by the financial crisis, as well as to present alternatives. This part presents a successful combination of empirical and theoretical approaches to housing policy and right to food, adopting and formulating approaches at local, national and international level. Authors of the articles notice that austerity measures have disproportionally affected the least well-off and fostered the better situated which poses some serious questions with regard to their conformity with principles such as non-discrimination. They argue that a rights-based approach would be beneficial for the reconstruction of the system and its subsequent efficiency. For instance, Magdalena Sepúlveda Carmona suggests that spending cuts should be reviewed with regard to the groups mostly affected and checked if they do not violate the requirement for non-discrimination (important since Committee on Economic, Social and Cultural Rights requires to devote more resources to the discriminated groups). This is especially crucial since in most countries cuts are largely disproportional, i.e. affecting some social spheres to a much bigger extent than others. More importantly, Sepúlveda Carmona suggests that the way and the outcomes of austerity are not transparent for citizens, which itself may be not compliant with either transparency or accountability mechanisms that are part of human rights (although probably more third than the second generation). Even if we treat

T. Piketty, Capital in the Twenty-First Century, Cambridge 2014. 
the economic crisis as an external factor, its effects may be distributed in a manner that should fulfill the requirements of human rights, including non-discrimination. One of the key issues is providing the government with sufficient funding for public services, which was mainly done by consumption tax increases, disproportionally touching the less well-off. If there are empirical studies showing that if only anti-tax evading policy were introduced, one could avoid the cuts potentially harmful for human rights condition (as Nicolas J. Lusiani notices in the book) how should one approach this fact?

Second part of the book revolves around a legal analysis of ESR duties, including most importantly the scope and content of Article 2(1) of the International Covenant on Economic, Social and Cultural Rights (hereinafter: ICESCR), with a stress put on the possibility of evaluating the harmful impact of austerity measures on human rights on the basis of the prohibition on "deliberate" retrogressive measures with regard to ESR standards. The authors note numerous difficulties with the use of this solution, and that although the principle has been concretized as a result of the crisis, theoretical and practical progress still needs to be made for the principle to be useful. The second article in this part argues that financial interdependencies of the global economy are of the greatest concern from the human rights perspective and that enforceability of extraterritorial obligations with regard to human rights should be more closely evaluated. The author notes that Maastricht Principles on Extraterritorial Obligation of States in the area of Economic, Social and Cultural Rights have been a huge development in defining the content and scope of extraterritorial ESR obligations.

The third part is concentrated on the regional and national responses to the economic crisis, both on a level of the observance of constitutional rules such as the principle of Sozialstaat in Europe or the doctrine of the "vital minimum" in Columbia, as well as on the general role of litigation and courts in the enforcement and protection of ESR during the crisis. The authors note that those general constitutional principles with which ESR are deeply linked serve rather as a cue for the legislator, or a "rhetorical commitment" of the governments, and courts are reluctant to review austerity measures with regard to conformity therewith. Such a possibility is profoundly analyzed here, both on a level of constitutional courts and ordinary litigation.

\section{3. "Good-old" capitalism nostalgia}

Some of the articles in the volume (most importantly Raquel Rolnik and Lidia Rabinovich's evaluation of the financialization of homeownership) are showing signs of what I would call nostalgia for the welfare state of the 1960s. The present austerity measures are analyzed as if what could be done is a simple revocation of the actions undertaken during the phase of the "disorganization" of capitalism ${ }^{2}$ and with a subsequent socialization of costs problems would simply vanish, as they were created by the New Right agenda emerging in the 1980s-1990s. For instance, Rolnik and Rabinovich claim that the housing finance policy implemented since the 1990s, which was based on private credit, is always discriminatory, and therefore in fact inconsistent with human rights. They suggest a stronger involvement of the state in housing instead. The problem is that even if it is true that the housing finance policy based on facilitating access to cheap credit is always discriminatory

\footnotetext{
S. Lash, J. Urry, The End of Organized Capitalism, Blackwell Publishers 1987; C. Offe, Disorganized Capitalism, Cambridge 1985.
} 
(a claim that I believe to be well grounded), it is questionable whether the dynamics can be reversed by the underlying suggestion of the return of the pre-monetarist "good-old" social housing policy from the golden era of capitalism. Growth based on financialization and widening of access to private credit, a solution that Colin Crouch called the "privatized Keynesianism", ${ }^{3}$ has been adopted after certain other courses of action, including inflation and "public" Keynesianism based on public debt, have reached their limits. The government policy with regard to tackling the old problem of "democracy versus markets" was simply to "buy time". ${ }^{4}$ It is questionable whether this form of nostalgic policy will produce positive effects and even more controversial whether it will not create new tensions and contradictions, as was the case in the past.

\section{Political manageability and the interdiction of retrogressive measures}

Cutting on health benefits in order to bailout banks that subsequently handed out enormous bonuses to their already super-rich CEOs is only an extreme example of how austerity may be in a moral sense violating human rights in order to foster a narrow elite, however a judicial ban of a mix of redesign/austerity measures would require the legal system to analyze the totality of the actions of the government, given that it would be ineluctable to assume a very holistic position. It seems that it would cause the legal system to strongly influence and interfere with the political dynamics. It would therefore necessitate the legal system interfering with the democratic mechanisms themselves.

Although the editor of the book explicitly states that the structure of ESR does not require states to adopt specific policy measures, questions on the possibility of the democratic community to review and possibly abolish some of the existing institutions emerge. As was noted by some authors, certain solutions that now ESR are composed of (social benefits etc.) were adopted during the "good years" of the golden era of capitalism and were cheap at the beginning, but became an increasingly substantial financial burden as the situation developed. ${ }^{5}$ One of the primary examples is the generation-solidaritybased pension system that was introduced during a demographic boom and when the boom stopped, it has become a financial burden of grandeur it had never been intended to be. Following the various General Comments issued by the Committee on Economic, Social and Cultural Rights, one of the ways in which ESR could be protected would be a prohibition on "deliberate" retrogressive measures with regard to ESR protection other than in very limited circumstances. The problem is of great complexity. On the one hand, one should keep the promises of the welfare state (including, one may say, even the "inflated" ESR) which people have got used to, in order to promote solidarity and uncertainty-reducing trust in the institutional framework, especially since it protects the individual. On the other hand, a question arises whether this kind of perspective does not bind the scope of the democratic will of the future generations. Why should current generations be forced to respect the institutions adopted decades ago ("inheritance", as Richard Rose brilliantly described it) and where is in this respect a fiscal democracy? As Helen Hershkoff and Stephen Loffredo note in the book, the welfare state itself was

C. Colin, Privatised Keynesianism: An Unacknowledged Policy Regime, The British Journal of Politics \& International Relations, 2009/3, pp. 382-399.

W. Streeck, Buying Time: The Delayed Crisis of Democratic Capitalism, London-New York 2014.

E.g. R. Rose, Inheritance before choice in public policy, Journal of Theoretical Politics, 1990/2, pp. 263-91; R. Rose, P.L. Davies, Inheritance in Public Policy: Change without Choice in Britain, New Haven 1994. 
designed as a countercyclical measure, there are however numerous ideas on the role of the public sphere in the economy and a democratic political community should be able to choose them freely. This is especially crucial since the form in which the ESR are institutionalized is subject to the democratic will so that the "ontological", "objective" or even "transnational" perspective cannot be adopted easily. The problem of the "hegemonic" "neoliberal" character of the democratic discourse, the real manageability of the nationstate in a world dominated by international financial institutions, the domination of elites over the "true" democratic community or even of the prevalence of the "bourgeois" interests in the capitalist democracies is of another order. Deriving specific solutions from the internationalization of human rights, e.g. by interpreting Article 2(1) ICESCR as an instrument that prevents the adoption of austerity measures, betrays a mindset very similar to one saying that austerity must be implemented because of the obligations made by the state with regard to IMF or World Bank. That is also reflected in the Covenant decisions to evaluate with extreme caution the various social policy decisions of states in the crisis as potentially violating human rights. The problem is, of course, that both IMF and World Bank were not so moderate in promoting their agenda.

\section{Normalization vs. administratization}

Some problems are, in my opinion, the political implications of assuming human rights recovery, especially due to the interdependencies between the local and global level. Ensuring human rights observance in a globalized world would demand, what can clearly be seen in the article written by Olivier De Schutter in the book, a significant shift from the normative to administrative mechanisms of the political system, i.e. public policy should become more goal- and less norm-oriented, therefore the norms themselves (except for those specifying the content of rights) should become more general, whereas the scope of administrative intervention should be widened. International governance must be flexible and reactive towards the ever-changing situation. It creates some serious problems with regard to the manageability and subjectivity of decision-making and, paradoxically, may lead to the domination of "independent experts" from the international institutions such as IMF or World Bank, the ultimate bearers of economic knowledge in the world. Given that the administratization of the modern states is at least partially responsible for the rise of the unaccountable politico-financial elite that used complex administrative-political decisions in order to carry out reforms favorable for the financial sector, what confidence can we really put in the expansion of the administrative power?

\section{Economic and social rights as human rights between openness and institutionalization}

Another problem with using human rights as tools of politico-legal influence is related to the issue of their institutionalization. On the one hand, ESR, even if they can be transformed into direct claims towards the state, are still difficult to institutionalize due to their elusive character. One the other hand, it is necessary to provide them with institutionalization to ensure their enforceability. As a result, the concept of ESR understood as human rights tries to achieve two goals difficult to reconcile at the same time - to be an open claim towards the constant improvement of the human condition compliant with the modern idea of progress, and at the same time to be an institutionalized claim able 
to verify specific solutions and decisions made by the various actors bound to respect human rights (especially the state). Emphasizing the first aspect means that one can presume the possibility of the constant improvement but is somewhat defenseless to the claims that we need to "go back in order to go forward" (for instance, carry out "neoliberal" reforms in order for the economy to "trickle down" to the less well-off). Quoting Keynes' words that "in the long run we are all dead" means nothing if the neoclassical theory is right that the provision of human rights is in fact averted by the very means aiming at their realization (whether that is true is not of interest to me here except for my belief that the political community may assume such an approach). The second option, which assumes institutionalization, means that one converts ESR into "simple" rights and puts them in the legal system, which is both philosophically controversial, and puts one in a position to determine the exact content of ESR, which is even more difficult.

I believe that human rights can be a path to recovery but only when one looks at them as a way of redesigning the relations between the functionally differentiated subsystems of the society, i.e. as a way of finding balance between the economy and politics or, one can say, capitalism and democracy. Luhmann argued that human rights serve as protective mechanisms of the functionally differentiated society against the tendencies of the de-differentiation. ${ }^{6}$ In short, social subsystems that form a society may try to expand and subordinate spheres in which they would not be functional. For instance, the political subsystem may try to subordinate the economic subsystem, but because the driving agenda of the political subsystem is not compliant with the rules of the economic subsystem, that would not be propitious for the society - and vice versa. ${ }^{7}$ In this perspective, the financial crisis may be perceived as being caused by the de-differentiation launched by an expansion of the economic subsystem to the spheres that should not operate with the binary code of the economy (payment/non-payment). Human (or fundamental) rights are an institution that serves to prevent the interference of the different functional spheres in the society for the sake of functional differentiation, in order to - ultimately - assure the inclusion of an individual and protect him/her. ${ }^{8}$ Human rights assure that the access to different functional subsystems is open and provided within the logic of this functional subsystem. ${ }^{9}$ They are violated when the right to access to some of the functional subsystems of the society (e.g. healthcare, education) is regulated not by the specific criteria characteristic for this system (e.g. level of illness; lack and need for education) but within the criteria of another system (e.g. economic or political one), i.e. when the mechanisms of societal inclusion are not sufficiently heterogeneous..$^{10}$ In this perspective, human rights are not a part of either legal or economic subsystem, but rather "institutionalized expectations which underlie the legal system"11 and that can structure the relations between differentiated subsystems of the society.

${ }^{6}$ For a different interpretation of Luhmann's approach to human rights, see: H.-G. Moeller, 'Human Rights Fundametalism'. The Late Luhmann on Human Rights, Soziale Systeme, 2008/14, pp. 126-141.

Luhmann was mainly concerned with the expansion of the political system but nowadays we have new candidates that are as expansive as the political system in the past - economy and technology - C.B. Graber, G. Teubner, Art and Money: Constitutional Rights in the Private Sphere?, Oxford Journal of Legal Studies, 1998/1, p. $66 \mathrm{ff}$.

N. Luhmann, Grundrechte als Institution: Ein Beitrag zur politischen Soziologie, Berlin 2009.

N. Luhmann, Law as a Social System, Oxford 2004, p. 135.

10 G. Verschraegen, Differentiation and Inclusion, in: M. R. Madsen, G. Verschraegen (eds), Making Human Rights Intelligible. Towards a Sociology of Human Rights, Oxford-Portland 2013, pp. 71-74

11 G. Verschraegen, Human Rights and Modern Society: A Sociological Analysis from the Perspective of Systems Theory, Journal of Law and Society, 2002/ 2, p. 263. 
Of course, this does not give specific answers on what to do, but makes it possible to maintain the human rights recovery perspective and at the same time to escape from the wastelands of both economic recovery and human rights approach based on the closure of their institutionalization or on the impossibility to institutionalize their openness. Calls that can be found in the book for constitutional courts to exercise more courage with regard to reviewing austerity measures may be of use here.

\section{Towards a systems theory interpretation of the crisis}

The problem of the "causes" of the crisis and the "responses" thereto is another area in which I believe a systems theory approach may be of use. In a way, the underlying assumption of the book is compliant with the dominant approach that the crisis itself should be treated as a factor external to the financial and legal developments that followed its occurrence. I believe that this is not the most accurate interpretation. If one assumes that the functional differentiation of the modern society covers the economic subsystem (which is, I believe, indisputable), the crisis should be treated as a self-description of the societal (political and economic) disturbances and not as an element of the "environment". The idea is not to say that the crisis is a subjective state of the "societal mind" but rather that there is a difficulty to precisely differentiate between what adds up to the crisis itself - are these only the financial causes or also the responses thereto. I believe that assuming this approach could help the authors to better explain the deteriorating condition of human rights. As authors note, the principal link between the worsening condition of human rights is not to the crisis "itself" (whatever it may mean) but rather to the specific solutions undertaken as ways of dealing with it. This could better show why imposing, for instance, spending cuts in the essential healthcare instead of introducing anti-tax-evasion policies is essentially wrong from the human rights perspective - because the crisis as such is a self-description of the condition of societal disturbances which can be managed through different measures, including those prone to create self-propelling dynamics such as public austerity (the situation is bad, so one must introduce harsh instruments, then it becomes worse, therefore more rigid measures must be undertaken, etc.). In the end, the indicators for the "reality" of the crisis are the public austerity measures that were introduced as a way of responding to it.

\section{Summary}

The book provides many important ideas and remarks on the human rights dimension of the crisis. It however does not hide that many theoretical developments must be made in order for this approach to be applicative and fruitful. The single most important thought of the book is that the perspective of human rights as a burden for the post-crisis recovery must be changed and that human rights can be beneficial for drafting solutions for the future. There are however numerous obstacles, mainly legal and political, to making this possible. The reviewed book identifies them accurately and convincingly tries to show some alternatives that may be of use. I however believe that the problem is not only of politico-legal nature, but also with the construction of ESR itself. A change in the perspective in the understanding of the role of ESR, from a "static" interpretation as rights to a more functional approach supported by systems theory, could be useful in providing a new perspective. 


\section{BIBLIOGRAFIA / REFERENCES:}

Colin, C. (2009). Privatised Keynesianism: An Unacknowledged Policy Regime. The British Journal of Politics \& International Relations 11/3, 382-399.

Graber, C.B., Teubner, G. (1998). Art and Money: Constitutional Rights in the Private Sphere? Oxford Journal of Legal Studies 18/1, 61-74.

Lash, S., Urry, J. (1987). The End of Organized Capitalism. Madison: University of Wisconsin Press.

Luhmann, N. (2009). Grundrechte als Institution: Ein Beitrag zur politischen Soziologie. Berlin: Duncker \& Humblot.

Luhmann, N. (2004). Law as a Social System. Oxford: Oxford University Press.

Moeller, H.-G. (2008). 'Human Rights Fundametalism'. The Late Luhmann on Human Rights. Soziale Systeme 14/1, 126-141.

Offe, C. (1985). Disorganized Capitalism. Cambridge: Cambridge University Press.

Piketty, T. (2014). Capital in the Twenty-First Century. Cambridge: Cambridge University Press.

Rose, R. (1990). Inheritance before choice in public policy. Journal of Theoretical Politics 2/3, 263291.

Rose, R., Davies, P.L. (1994). Inheritance in Public Policy: Change without Choice in Britain. New Haven: Yale University Press.

Streeck, W. (2014). Buying Time: The Delayed Crisis of Democratic Capitalism. London-New York: Verso.

Verschraegen, G. (2013). Differentiation and Inclusion. In M. R. Madsen, G. Verschraegen (Eds.), Making Human Rights Intelligible. Towards a Sociology of Human Rights. Oxford-Portland: Hart Publishing.

Verschraegen, G. (2002). Human Rights and Modern Society: A Sociological Analysis from the Perspective of Systems Theory. Journal of Law and Society 29/2, 258-281. 